\title{
Çocuk ve ergen psikiyatri polikliniğine başvuran olguların beden kitle indeksi, beslenme tutum ve davranışları: duygusal ve davranışsal sorunlarla ilişkisi
}

\author{
Body mass index, nutrition attitude and behavior of the cases who applied to child \\ and adolescent psychiatry outpatients: the relation with emotional and behavioral \\ problems
}

Ömer Başay, Bürge Kabukçu Başay, Cihan Erbay, Onur Coşkun, Burçin Sağıroğlu

Öz

Amaç: Çocuk ve ergenlerdeki ruhsal bozukluk belirtileriyle beden kitle indeksi ve beslenme tutum ve davranışları arasında ilişkiler bulunmaktadır. Bu çalışmanın amacı Çocuk ve Ergen Ruh Sağığı ve Hastalıkları polikliniklerine başvuran olguların beden kitle indeksi, beslenme tutum ve davranışlarını değerlendirmek ve bu tutum ve davranışlarla duygusal ve davranışsal sorunlar arasındaki ilişkiyi incelemektir.

Gereç ve yöntem: Çocuk ve ergen psikiyatrisi polikliniklerine başvuran 11-16 yaş arası 169 kişi çalışmaya katılmıştır. Katııımcıların içe yönelim ve dışa yönelim sorunları Güçler ve Güçlükler Anketi (GGA) Ergen Formu ile beslenme tutum ve davranışları Beslenme Tutum Ölçeği (BTÖ) ve Beslenme Davranış Ölçeği (BDÖ) ile değerlendirilmiştir. Çalışmaya katılan gönüllülerin kilo ve boyları ölçülerek beden kitle indeksleri hesaplanmıştır. Bulgular: Çalışmaya katılanların \%9,5'i obez, \%10,1'i aşırı kilolu, \%65,5'si normal kilolu olarak saptanmıştır. BTÖ ve BDÖ toplam puan ortalamaları sırasıyla $8,29 \pm 2,85$ ve $-1,69 \pm 4,79$ 'dir. BTÖ toplam puanı ile GGA davranış sorunları puanı $(r=-, 233, p=0,003)$; hiperaktivite puanı $(r=-, 344, p<0,001)$ ve toplam güçlük puanı $(r=-$ ,281, $p<0,001)$ arasında negatif yönlü bir ilişki mevcuttur. BDÖ toplam puanı ile GGA sosyal davranışlar puanı arasında pozitif yönlü $(r=, 216, p=0,005)$ bir ilişki bulunmuştur.

Sonuç: Çocuk ve ergen psikiyatri polikliniklerine başvuran çocuk ve ergenlerde sağlıksız beslenme tutum ve davranışları fazladır. Dışa yönelim sorunları ve toplam duygusal-davranışsal güçlük arttıkça; sosyal davranışlar azaldıkça sağlıksız beslenme artmaktadır. Beslenme tutum ve davranışları ile psikiyatrik faktörlerin ilişkisinin belirlenmesi hem beslenme hem de ruhsal sorunların anlaşılması ve önlenmesi konusunda yol gösterici olabilir.

Anahtar kelimeler: Diyet alışkanlıkları, içeyönelim sorunları, dışayönelim sorunları, ruh sağlığı.

Başay Ö, Kabukçu Başay B, Erbay C, Coşkun O, Sağıroğlu B. Çocuk ve ergen psikiyatri polikliniğine başvuran olguların beden kitle indeksi, beslenme tutum ve davranışları: duygusal ve davranışsal sorunlarla ilişkisi. Pam Tıp Derg 2021;14:402-415.

\begin{abstract}
Purpose: There are relationships between mental disorder symptoms in children and adolescents with body mass index, and nutritional attitudes and behaviors. The aim of this study was to evaluate the body mass index, nutritional attitudes and behaviors of the cases who admitted to child and adolescent psychiatry outpatient clinics and to examine the relationship between these attitudes and behaviors and emotional and behavioral problems.

Materials and methods: 169 subjects aged 11-16 years who applied to child and adolescent psychiatry outpatients participated in the study. Participants' internalizing and externalizing problems were evaluated with the Strength and Difficulties Questionnaire (SDQ) Adolescent Form, nutritional attitude and behaviors with Nutrition Attitude Scale (NAS) and Nutrition Behavior Scale (NBS). Body mass indexes were calculated by measuring the weight and height of the volunteers participating in the study.
\end{abstract}

Ömer Başay, Dr. Öğr. Üye. Pamukkale Üniversitesi Tıp Fakültesi, Çocuk ve Ergen Ruh Sağıı̆ı ve Hastalıkları Anabilim Dalı, Denizli, Türkiye, e-posta: omerbasay@gmail.com (https://orcid.org/0000-0001-7816-3983) (Sorumlu Yazar)

Bürge Kabukçu Başay, Dr. Öğr. Üye. Pamukkale Üniversitesi Tıp Fakültesi, Çocuk ve Ergen Ruh Sağlığı ve Hastalıkları Anabilim Dalı, Denizli, Türkiye, e-posta: burgekabukcu@yahoo.com (https://orcid.org/0000-0003-4124-2340)

Cihan Erbay, Pamukkale Üniversitesi Tıp Fakültesi, Dönem III öğrencisi, Denizli, Türkiye, e-posta: cihanerbay61@gmail.com (https://orcid.org/0000-0002-7091-732X)

Onur Coşkun, Pamukkale Üniversitesi Tıp Fakültesi, Dönem III öğrencisi, Denizli, Türkiye, e-posta: onurcoskun2008@ windowslive.com (https://orcid.org/0000-0001-9101-1933)

Burçin Sağıroğlu, Pamukkale Üniversitesi Tıp Fakültesi, Dönem III öğrencisi, Denizli, Türkiye, e-posta: burcinsagiroglu@ gmail.com (https://orcid.org/0000-0002-0882-1730) 
Results: $9.5 \%$ of the participants in the study were found to be obese, $10.1 \%$ overweight and $65.5 \%$ normal weight. The total mean scores of NAS and NBS were $8.29 \pm 2.85$ and $-1.69 \pm 4.79$, respectively. There was a negative correlation between total NAS score and SDQ behavioral problems score $(r=-.233, p=0.003)$; hyperactivity score $(r=-.344, p<0.001)$ and total difficulty score $(r=-.281, p<0.001)$. A positive relationship was found between total NBS score and SDQ social behavior score $(r=.216, p=0.005)$

Conclusion: Children and adolescents who admitted to child and adolescent psychiatry outpatient clinics have many unhealthy eating attitudes and behaviors. Unhealthy nutrition increases as the externalizing problems and total emotional and behavioral difficulties increase and as the social behaviors decrease. Determining the relationship between nutritional attitudes and behaviors and psychiatric factors can be a guide for understanding and preventing both nutritional and mental problems.

Key words: Dietary habits, internalizing problems, externalizing problems, mental health.

Basay O, Kabukcu Basay B, Erbay C, Coskun O, Sagıroglu B. Body mass index, nutrition attitude and behavior of the cases who applied to child and adolescent psychiatry outpatients: the relation with emotional and behavioral problems. Pam Med J 2021;14:402-415.

\section{Giriş}

Aşırı kilo ve obezite, küresel olarak en yaygın halk sağlığı sorunlarının başında gelmektedir ve yalnızca yetişkinlerde değil aynı zamanda çocuklarda ve ergenlerde de epidemik boyuttadır [1, 2]. Gelişmiş ülkelerde 20 yaş altındaki erkeklerin \%23,8'inin, kızların $\% 22,6$ 'sının aşırı kilolu veya obez olduğu bildirilmiştir [2]. Türkiye Beslenme ve Sağlık Araştırması-2010 sonuçları ülkemizde 6-18 yaş arasındaki obezite sıklığını $\% 8,2$, aşırı kilolu olma sıklığını \%14,3 olarak bildirmiştir [3]. Psikiyatrik bozukluğa sahip olanlar, aşırı kilo/obezite açısından özellikle riskli bir grup olarak tanımlanmıştır. Bazı çalışmalar çocuk ve ergen psikiyatri klinik popülasyonlarında sağlıklı kontrollere kıyasla daha yüksek aşırı kilo ve obezite oranları olduğunu göstermiştir $[4,5]$. Türkiye'de çocuk ve ergen psikiyatri örneklemini bu açıdan inceleyen bir çalışmaya ulaşılamadığından ülkemizdeki durum bilinmemektedir.

Ergenlerdeki ruhsal bozukluk belirtileriyle artan beden kitle indeksi (BKI) arasındaki olası bağıntıyı değerlendiren araştırmaların bir kısmında BKI ile ruh sağlığı arasında ilişki bulunurken, bazı çalışmalar bu yönde bir ilişki tespit edememiştir [6-10]. Ayrıca çalışma sonuçları seçilen örnekleme göre de değişiklik göstermektedir. Örneğin, depresyon klinik örneklemde BKi ile ilişkili bulunurken, toplum temelli çalışmalarda böyle bir ilişki saptanmamıştır [11]. Çocukluk çağında obezitenin içe yönelim semptomlarıyla bağıntılı olduğuna dair hem kesitsel hem de izlemsel çalışmalardan elde edilen kanıtlar mevcuttur [12]. Normal BKI olan olgulara göre aşırı kilolu/obez erkeklerde dışayönelim sorunları; kızlarda da içeyönelim sorunları daha fazla görülmektedir [13, 14]. Türkiye'de ise çok az sayıda araştırma bu ilişkiyi incelemiştir. OtçekenKurtaraner'in (2012) toplum örnekleminde 1417 yaş ergenlerle yaptığı çalışmada BKI ile depresyon, anksiyete düzeyleri ve beslenme alışkanlıkları arasında istatistiksel açıdan anlamlı bir ilişki bulunamamıştır [15]. Bu alanda yapılmış çalışma sonuçları yorumlanırken artan BKI ve ruhsal sorunlar arasındaki ilişkinin iki yönlü olduğunun dikkate alınması gerektiği belirtilmektedir [16]. Yazındaki kısıtlı veriler göz önünde bulundurulduğunda, ergenlik dönemindeki ruh sağlığı ve BKI arasındaki olası ilişkinin bizim toplumumuzda incelenmesine intiyaç olduğu görülmektedir.

Beslenme, kişilerin sağlığını korumak ve sürdürebilmek için vücudun gereksinim duyduğu besin öğelerini yeterli miktarlarda ve uygun zamanlarda alma eylemi olarak tanımlanabilir [17]. Sağlıksız besin tüketimi, meyve ve sebze alımının yetersiz olması, tatlandırımış içecek, şekerli, yağlı ve tuzlu atıştırmalık tüketiminde artış veya düzensiz kahvaltı yapımı şeklinde tanımlanmıştır $[18,19]$. Sağlıksız besin tüketimi, aşırı kilo ve obezite ile ilişkilidir [20]. Ergenlik, genellikle öğün atlama, sık atıştırma ve büyük miktarlarda sağlıksız yiyecek tüketme gibi gıda alımında olumsuz değişikliklerin gözlendiği bir dönemdir [21]. Ergenlerdeki sağlıksız beslenme alışkanlıkları, yetişkinlikte de devam etme eğilimi göstermektedir ve yaşamın ileriki evrelerinde metabolik sendrom, diabetes mellitus veya kanser gibi olumsuz sağlık sonuçlarıyla bağlantılıdır [22, 23].

Ergenlerde beslenme kalitesini ruh sağlığıyla ilişkilendiren çalışmalar vardır. İngiltere'de yaklaşık 3.000 ergen (11-14 yaş) üzerinde 
yapılan kesitsel bir çalışma, Güçler ve Güçlükler Anketi (GGA) ile değerlendirilen zihinsel sağlık semptomlarıyla sağlıksız gıda alımı arasında bir ilişki bulmuştur [24]. Jacka ve ark. [25], 1118 yaş arası gençlerde, daha yüksek sağlıklı beslenme kalitesi puanları ile ruh sağlığı arasında bir bağıntı raporlamıştır. Avustralya'da yapılan bir çalışma, daha az sağlıklı gıda tüketen 10-14 yaşındaki çocuk ve gençlerin depresif belirtilere sahip olma olasılığının arttığını bildirmiştir [26]. Benzer şekilde, 10 yaşındaki 3.300 Alman çocuk üzerinde yapılan bir çalışma, daha yüksek beslenme kalitesi puanlarının, GGA'da daha düşük emosyonel semptomlar ile ilişkili olduğunu göstermiştir [27]. Koreli ergenlerde de sağlıksız gıda tüketimi ile mutsuzluk, üzüntü, intihar düşünce ve planları arasında ilişki saptanmıştır [28]. Yakın zamanda yapılan bir meta analiz çalışması ise sağlıksız beslenmenin dikkat eksikliği ve hiperaktivite riskini artırdığını ortaya koymuştur [29]. Bununla birlikte 746 ergenin değerlendirildiği bir çalışmada, sağlıksız besin tüketiminin dışa yönelim sorunları ile ilişkisi sadece kızlarda gösterilmiştir [30]. Literatürün sistematik bir incelemesi, çocuklarda ve ergenlerde sağlıksız beslenme ve daha kötü ruh sağlığı arasındaki ilişki için bazı tutarlı kanıtlar olduğu sonucuna varmış, ancak bu konuda daha fazla araştırma yapılması gerektiğine dikkat çekmiştir [31].

Çocuk ve ergen psikiyatrisi polikliniklerine başvuran çocuk ve ergenlerin beslenme tutum ve davranışlarının ve bunların duygusal ve davranışsal sorunlar ile olası ilişkisinin araştırılması, aşırı kilolu ve obez olma gibi sağlık sorunlarının çözümünde ve beslenme ile ruh sağlığı arasındaki ilişkinin anlaşılmasında rol oynayabilir. Çalışmamızdaki hipotezlerimiz; çocuk ve psikiyatri polikliniklerine başvuran olguların toplum örneklemlerinden elde edilen genel verilere göre daha obez ve aşırı kilolu saptanacağı, ayrıca duygusal ve davranışsal sorunlarla ilişkili daha kötü beslenme alışkanlıklarına sahip olacağıdır. Bu nedenle, çalışmamızın amacı çocuk ve ergen psikiyatrisi polikliniklerine çeşitli sebeplerle başvuran olgularda obez ve aşırı kilolu olanların oranlarını belirlemek, ayrıca başvuruda bulunan çocuk ve ergenlerin beslenme tutum ve davranışlarını değerlendirerek, bu tutum ve davranışlarla duygusal ve davranışsal sorunlar ve beden kitle indeksi arasındaki ilişkiyi ülkemizde ilk defa incelemektir.

\section{Gereç ve yöntem}

Araştırmamı, Pamukkale Üniversitesi Tıp Fakültesi Çocuk ve Ergen Ruh Sağlığı ve Hastalıkları Poliklinikleri'ne iki aylık bir zaman dilimi içerisinde başvuran 11-16 yaş arası çocuk ve ergenlerin katılımıyla kesitsel bir çalışma olarak tasarlanmıştır. Bu dönem içerisinde çalışma örneklemini oluşturmak üzere 196 çocuk ve ergen değerlendirilmiş, bunlar arasından çalışmaya katılmayı kabul eden ve çalışmaya dahil olma kriterlerini karşılayan 169 ergen çalışma örneklemini oluşturmuştur. Çalışmaya dahil olma kriterleri, çocuk veya gencin ek tıbbi bir hastalık tanısı olmaması, son bir hafta içerisinde enfeksiyon tablosunun bulunmaması, klinik olarak formları anlamasına ve doldurmasına engel olacak düzeyde zekâ geriliği veya otizm düşündürecek tanı ve belirtilerinin bulunmaması, akut manik atak veya psikoz tanısı almamış olması, çalışma formlarını eksiksiz ve güvenilir şekilde doldurması ve kendisi ve ebeveyninin çalışmaya katılmaya gönüllü olması olarak belirlenmiştir. Klinik olarak zekâ değerlendirmesi; akıl yürütme, sorun çözme, tasarlama, soyut düşünme, yargılama, okulda öğrenme ve deneyimlerinden öğrenme gibi anlıksal işlevleri, toplumsal ve uyumsal işlevsel kısıtlılıklar ile geçmiş tanı öyküsü dikkate alınarak yapılmıştır. Yüz doksan altı kişinin 17'sinde çocuk, ergen ya da aile çalışmaya katılmayı kabul etmemiştir. Altı kişi eksik form teslim ettiği, 2 kişi otizm spektrum bozukluğu, 1 kişi mental retardasyon ve 1 kişi de akut psikotik atak tanıları nedenleriyle çalışmaya alınmamış, böylece toplam 169 çocuk ve ergen çalışmaya katılmıştır. Çalışma, Pamukkale Üniversitesi Tıp Fakültesi Klinik Araştırmalar Etik Kurulu'ndan onay alındıktan sonra başlamış ve çalışmaya katılmaya kendisi ve ailesi onam veren katılımcılar ile gerçekleştirilmiştir. BKi değerleri vücut ağırlı̆ının $(\mathrm{kg})$ boyun karesine $\left(\mathrm{m}^{2}\right)$ bölünmesiyle hesaplanmış, ardından Türk çocukları için yaş ve cinsiyete göre belirlenmiş olan standart değerlere göre $5 \leq \mathrm{BK} \mid<85$ arası normal kilolu, $85 \leq B K \dot{1}<95$ persentil aşırı kilolu, $B K i \geq 95$ persentil üstünde ise obez olarak tanımlanmıştır [32]. Örneklem grubundaki çocuk ve ergenler ile ilgili sosyodemografik özellikleri sorgulayan sosyodemografik veri formunu aileler; Güçler ve Güçlükler Anketi, Beslenme Tutum Ölçeği ve Beslenme Davranış Ölçeğini çocuk ve ergenler poliklinik bekleme salonunda doldurmuşlardır. 


\section{Çalışmada kullanılan ölçekler}

1- Sosyodemografik veri formu: Çocuk ve aile ilgili sosyodemografik özellikleri toplamak için araştırmacılar tarafından oluşturulmuştur. Formda çocuğun yaşı, cinsiyeti, anne ve babanın eğitim durumu ve ailenin gelir durumunu sorgulayan sorular yer almıştır. Ayrıca çalışmaya katılan çocuk ve ergenlerin kilo ve boyları ölçülerek beden kitle indeksleri hesaplanmış ve forma not edilmiştir.

2-Güçler ve Güçlükler Anketi (GGA) Ergen Formu: Goodman [33] tarafından 1997 yılında geliştirilmiştir. Ölçeğin iç tutarlığını yansıtan Cronbach alfa değeri 0,73, 4-6 hafta sonra uygulanan re-test stabilitesi 0,62 'dir. Türkçe geçerlilik ve güvenilirliği Güvenir ve ark. [34] tarafından yapılmıştır. Bu anket 25 soru içerir ve 11-16 yaş arası gençlerin kendilerini değerlendirmesi için kullanılmaktadır. Ölçekte davranış sorunları, dikkat eksikliği ve aşırı hareketlilik, duygusal sorunlar, akran sorunları ve sosyal davranışlar olmak üzere 5 alt boyut vardır. Illk dört başığın toplamı ile "toplam güçlük puanı" hesaplanmaktadır. Bu çalışmada ölçeğin toplam iç tutarlılık katsayısı ,66 olarak bulunmuştur.

3-Beslenme Tutum Ölçeği (BTÖ): Arvidson [35] (1990) tarafından çocukların kalp sağlığını geliştirmeye yönelik tutumlarını değerlendirmek amacıyla geliştirilen ve 16 maddeden oluşan Çocuk Kalp Sağlığını Geliştirme Tutum Ölçeği (Children's Cardiovascular Health Attitude Scale) Türk toplumuna Haney ve Bahar [36] (2014) tarafından uyarlanmıştır. Ölçek dört alt testten oluşmaktadır: 1. Egzersiz- 4 madde; 2. Beslenme- 4 madde; 3 . Sigara içme- 4 madde 4. Stres kontrolü- 4 madde. Bu çalışmada sadece "beslenme" alt ölçeği kullanılmıştır. Ölçeğin iç tutarlılık güvenirlik katsayısı 0,79 , beslenme alt ölçeğinin iç tutarlık güvenirlik katsayısı 0,68'dir. Beslenme alt ölçeği çocuğun yağ alımını azaltan, sağlıkı yiyecek tüketimini artıran aktivitelere ve kalp sağlığını iyileştiren beslenme biçimine yönelik tutumunu ölçer. Ölçek maddeleri 1-4 puan aralığında (1- kesinlikle katılmıyorum, 4- kesinlikle katılıyorum) değer almaktadır, toplam puanı 4-16 arasındadır. Ölçekten alınan toplam puanın yüksek olması olumlu tutumu göstermektedir [36]. Bu çalışma için iç tutarlılık katsayısı 0,73 olarak hesaplanmıştır.
4-Beslenme Davranış Ölçeği (BDÖ): Beslenme davranışlarının belirlenmesinde Edmundson ve ark. [37] (1996) tarafından geliştirilen Öztürk ve Erdoğan [38] (2010) tarafından Türk çocuklarına uyarlanan Beslenme Davranış Ölçeği kullanılmıştır. Ölçek, çocukların besin tüketimlerini belirlemek için az yağı/tuzlu ve çok yağlı/tuzlu besin seçeneklerinin olduğu resimli 14 maddeden oluşmuştur. Çocuklara karşılaştırılabilir besinler gösterilerek iki besin arasından hangisini daha çok (sık) yediği sorulmuştur. Ölçek maddeleri sağlıksız besin için -1 , sağlıklı besin için +1 değer almaktadır, toplam puanı $-14,+14$ arasındadır. Ölçekten alınan toplam puanın yüksek olması sağlıklı beslenme alışkanlığını göstermektedir. BDÖ iç tutarlılık güvenirlik katsayısı 0,74'tür [38]. $\mathrm{Bu}$ çalışma için ölçeğin iç tutarlııı güvenirlik katsayısı 0,71 bulunmuştur.

Verilerin analizi; istatistiksel değerlendirmeler "SPSS (Statistical Package for Social Sciences) for Windows 18.0" paket programında yapılmıştır. Sayısal veriler aritmetik ortalama (AO), standart sapma (SS), ortanca, çeyrekler arası aralık (ÇAA); kategorik veriler yüzde (\%) ve frekans ( $n$ ) değerleri verilerek tanımlanmıştır. Kategorik değişkenlerin karşılaştırılmasında Ki Kare Testi $\left(x^{2}\right)$, sürekli değişkenlerin iki grup karşılaştırmasında normal dağılım göstermeyenlerde Mann Whitney $U$ testi (z) kullanılmıştır. Sürekli değişkenlerin birbiriyle ilişkisinin incelenmesinde, normal dağılmayanlarda Spearman korelasyon testi (korelasyon katsayısı r) kullanılmıştır. Analizlerde \%95 güven aralığında anlamlılık değeri $p<0,05$ olarak kabul edilmiştir.

\section{Bulgular}

Katılımcıların yaş ortalaması 13,69'dur $(S S=1,85)$. Çalışmaya 81 'i $(\% 47,9) \mathrm{kIz}, 88^{\prime} \mathrm{i}$ $(\% 52,1)$ erkek 169 çocuk ve ergen katılmıştır. Çalışmada yer alan çocuk ve ergenlere ait bazı sosyodemografik özellikler ve kullanılan ölçeklerden elde edilen puan değerleri Tablo 1 'de sunulmuştur. Çalışmaya katılanların $\% 9,5$ 'i $(n=16)$ obez (BKi $\geq 95$ persentil üstünde), $\% 10,1^{\prime} i \quad(n=17)$ aşırı kilolu $(85 \leq B K i<95$ persentil), \%65,5'si ( $n=110)$ normal kilolu olarak saptanmıştır. Obezite kızlarda $(\% 14,8 \mathrm{n}=12)$ erkeklere $(\% 4,5 n=4)$ göre anlamlı derecede fazlaydı $\left(x^{2}=4,061 p=0,044\right)$. 
Tablo 1. Katılımcıların bazı sosyodemografik özellikleri ve beden kitle indeksi, Beslenme Tutum Ölçeği ve Beslenme Davranış Ölçeği puanları

\begin{tabular}{llll}
\hline & & N & AO $\pm \mathbf{S S}$ \\
\hline Yaş & & 169 & $13,69 \pm 1,85$ \\
Boy & & 169 & $158,92 \pm 12,39$ \\
Kilo & & 169 & $51,53 \pm 15,43$ \\
BKi & & 167 & $20,17 \pm 4,11$ \\
BTÖ & & 168 & $8,29 \pm 2,85$ \\
BDö & & 168 & $-1,69 \pm 4,79$ \\
& Kız & $\mathbf{N}$ & $\%$ \\
Cinsiyet & Erkek & 81 & 47,9 \\
& Ortaokul ve altı & 90 & 52,1 \\
Anne eğitim durumu & Lise ve üstü & 64 & 57,7 \\
Anne çalışma durumu & Çalışmıyor & 105 & 52,3 \\
& Çalışıor & 55 & 35,6 \\
Baba eğitim durumu & Ortaokul ve altı & 84 & 54,4 \\
Aile gelir & Lise ve üstü & 71 & 45,9 \\
& 2999 TL ve altı & 116 & 72,0 \\
\hline
\end{tabular}

$\mathrm{n}$ : frekans; AO: aritmetik ortalama SS: standart sapma BKI: beden kitle indeksi BTÖ: Beslenme Tutum Ölçeği, BDÖ: Beslenme Davranış Ölçeği

Ortaokul ve altı ile lise ve üstü olarak iki grupta değerlendirilen anne eğitim durumuna göre BTÖ ve BDÖ puanları açısından istatistiksel olarak anlamlı düzeyde farklılık saptanamadı $(p>0,05)$. Anne eğitimi lise ve üstü olan çocuk ve ergenlerin anne eğitimi ortaokul ve altı olanlara göre BKi oranları (sırayla ortanca $=20,41 \quad$ ÇAA $=4,35$; ortanca $=18,47$, ÇAA $=4,35$ ) istatistiksel olarak anlamlı olacak şekilde yüksekti $(z=2,490, p=0,013)$. Anne çalışma durumu (çalışıyor/çalışmıyor), baba eğitim durumu (ortaokul ve altı/lise ve üstü) ve aile gelir düzeyine göre (2999 TL ve altı/3000 TL ve üstü) BKI, BTÖ ve BDÖ arasında istatistiksel olarak anlamlı farklılık bulunmamıştır $(p>0,05)$.

BTÖ puanları açısından kızlar (ortanca $=8$, ÇAA $=3,5$ ) ve erkekler (ortanca=8, ÇAA=4) arasında istatistiksel olarak anlamlı bir farklılık yoktu $(z=-1,44, p=0,151)$. BDÖ puanları da kızlarda (ortanca $=-2$, ÇAA=6) ve erkeklerde (ortanca $=-2$, ÇAA $=6$ ) birbirinden anlamlı bir farklılık göstermedi ( $z=-0,81, p=0,416)$. BKI, kızlarda (ortanca $=19,82$, ÇAA $=5,41$ ) erkeklere (ortanca $=19, \quad C ̧ A A=5,47$ ) göre daha yüksek olmasına rağmen bu fark istatistiksel olarak anlamlı düzeyde değildi $(z=-1,934, p=0,053)$ (Tablo 2).
Katıımcıların BTÖ sorularına verdikleri cevaplar incelendiğinde çocuk ve ergenlerin "her sabah kahvaltı yapmayı seviyorum" cümlesine \%33,7'sinin katılmadığı \%40,8'inin kesinlikle katılmadığı, "sebze yemeyi seviyorum" cümlesine \%37,9'unun katılmadığı, \%29'unun kesinlikle katılmadığı tespit edilmiştir. BTÖ'ye çocuk ve ergenlerin verdiği cevaplar Tablo 3'te verilmiştir.

Çalışmamızda BKİ ile GGA alt ölçekler ve GGA toplam puanı arasında istatistiksel olarak anlamlı bir ilişki yoktur $(p>0,05)$. BKI'nin BTÖ toplam puanı ile arasında negatif zayıf bir ilişki saptanmış ( $r=-0,208, p=0,008)$, ancak BDÖ toplam puanı ile arasında anlamlı bir ilişki bulunmamıştır ( $r=-0,058, p=0,456)$ (Tablo 4).

BTÖ ve BDÖ toplam puanları ile GGA alt ölçek puanları ve toplam puanı arasındaki ilişki araştırıldığında, BTÖ toplam puanı ile GGA davranım sorunları, hiperaktivite ve dikkat eksikliği ve toplam güçlük puanı arasında hafiforta şiddette ters yönlü ilişki olduğu bulunmuştur (sırasıyla, $r=-0,233, p=0,003 ; r=-0,344, p<0,001$; $r=-0,281, p=0,008)$. BTÖ toplam puanı, GGA duygusal sorunlar, akran sorunları ve sosyal davranışlar ile istatistiksel 
Tablo 2. Cinsiyete göre Beslenme Tutum Ölçeği ve Beslenme Davranış Ölçeği toplam puanları ve beden kitle indeks değerleri

\begin{tabular}{llll}
\hline & $\mathbf{K} \mathbf{\prime z}(\mathbf{n}=\mathbf{8 1})$ & Erkek $(\mathbf{n}=\mathbf{8 7})$ & Toplam $(\mathbf{n = 1 6 8 )}$ \\
\hline & Ortanca (ÇAA) & Ortanca (ÇAA) & Ortanca $($ ÇAA) \\
BTÖ & $8(3,5)$ & $8(4)$ & $8(4)$ \\
BDÖ & $-2(6)$ & $-2(6)$ & $-2(6,75)$ \\
BKi & $19,82(5,41)$ & $19(5,47)$ & $19,6(5,32)$ \\
\hline
\end{tabular}

ÇAA: çeyrekler arası aralık, BTÖ: Beslenme Tutum Ölçeği,

BDÖ: Beslenme Davranış Ölçeği, BKi: beden kitle indeksi

Tablo 3. Katılımcıların beslenme tutum ölçeği cevapları

\begin{tabular}{lllll}
\hline BTÖ & $\begin{array}{l}\text { Kesinlikle } \\
\text { Katılıyorum } \\
\mathrm{n} \%\end{array}$ & $\begin{array}{l}\text { Katılıyorum } \\
\mathrm{n} \%\end{array}$ & $\begin{array}{l}\text { Katılmıyorum } \\
\text { n \% } \%\end{array}$ & $\begin{array}{l}\text { Kesinlikle } \\
\text { Katılmıyorum } \\
\mathrm{n} \%\end{array}$ \\
\hline $\begin{array}{l}\text { Her sabah iyi bir kahvaltı yapmayı } \\
\text { seviyorum }\end{array}$ & $13(7,7)$ & $30(17,8)$ & $57(33,7)$ & $69(40,8)$ \\
$\begin{array}{l}\text { Sebze yemeyi seviyorum } \\
\begin{array}{l}\text { Her gün sağlıklı besinler yemeyi } \\
\text { seviyorum }\end{array}\end{array}$ & $21(12,4)$ & $35(20,7)$ & $64(37,9)$ & $49(29,0)$ \\
$\begin{array}{l}\text { Okuldan sonra acıktığımda meyve } \\
\text { ya da benim için faydalı olduğuna } \\
\text { inandığım bir şey yiyorum }\end{array}$ & $17(10,1)$ & $40(23,7)$ & $69(40,8)$ & $45(26,6)$ \\
\hline
\end{tabular}

BTÖ: Beslenme Tutum Ölçeği

Tablo 4. Beslenme tutum ölçeği ve beslenme davranış ölçeği toplam puanı ile güçler ve güçlükler anketi puanları arasındaki ilişki

\begin{tabular}{|c|c|c|c|c|c|c|c|}
\hline GGA & $\begin{array}{l}\text { Davranış } \\
\text { sorunları }\end{array}$ & $\begin{array}{l}\text { Hiperaktivite/ } \\
\text { DE }\end{array}$ & $\begin{array}{l}\text { Duygusal } \\
\text { sorunlar }\end{array}$ & $\begin{array}{l}\text { Akran } \\
\text { ilişkileri }\end{array}$ & $\begin{array}{l}\text { Sosyal } \\
\text { davranışlar }\end{array}$ & $\begin{array}{l}\text { Toplam } \\
\text { puan }\end{array}$ & BKI \\
\hline BKI & $\begin{array}{l}r=-, 020 \\
p=0,756\end{array}$ & $\begin{array}{l}r=, 014 \\
p=0,858\end{array}$ & $\begin{array}{l}r=-, 039 \\
p=0,619\end{array}$ & $\begin{array}{l}r=-, 043 \\
p=0,589\end{array}$ & $\begin{array}{l}r=-, 027 \\
p=0,730\end{array}$ & $\begin{array}{l}r=-, 010 \\
p=0,901\end{array}$ & 1 \\
\hline BTÖ & $\begin{array}{l}r=-, 233^{* *} \\
p=0,003\end{array}$ & $\begin{array}{l}r=-, 344^{* *} \\
p<0,001\end{array}$ & $\begin{array}{l}r=-, 122 \\
p=0,116\end{array}$ & $\begin{array}{l}r=-, 109 \\
p=0,168\end{array}$ & $\begin{array}{l}r=, 124 \\
p=0,112\end{array}$ & $\begin{array}{l}r=-, 281^{* *} \\
p<0,001\end{array}$ & $\begin{array}{l}r=-, 208^{* *} \\
p=0,008\end{array}$ \\
\hline BDÖ & $\begin{array}{l}r=-, 112 \\
p=0,157\end{array}$ & $\begin{array}{l}r=, 030 \\
p=0,705\end{array}$ & $\begin{array}{l}r=, 054 \\
p=0,490\end{array}$ & $\begin{array}{l}r=-, 044 \\
p=0,582\end{array}$ & $\begin{array}{l}r=, 216^{* *} \\
p=0,005\end{array}$ & $\begin{array}{l}r=-, 014 \\
p=0,867\end{array}$ & $\begin{array}{l}r=-, 058 \\
p=0,456\end{array}$ \\
\hline
\end{tabular}

** $p=0,01$ derecesinde istatistiksel ilişki, GGA: Güç ve Güçlükler Anketi

BTÖ: Beslenme Tutum Ölçeği, BDÖ: Beslenme Davranış Ölçeği

BKI: beden kitle indeksi, DE: dikkat eksikliği

olarak anlamlı bir ilişki göstermemiştir $(p>0,05)$ (Tablo 4). BDÖ toplam puanı ise sadece GGA sosyal davranışlarla pozitif yönde ilişkili tespit edilmiştir $(r=0,216, p=0,005)$ (Tablo 4).

\section{Tartışma}

Çalışmamıza katılan çocuk ve ergenlerin $\% 9,5$ 'i obez, \%10,1'i aşırı kiloludur. Kızlarda obezite oranı $(\% 14,8)$, erkeklere göre $(\% 4,5)$ anlamlı derecede fazladır. Ülkemizde yakın zamanda toplum örnekleminde yapılan bir çalışmada 12-14 yaş arasında obezite oranı $\% 9,6$ aşırı kilolu olma oranı \%20,5 olarak bulunmuştur [39]. Dündar ve ark. [40] (2012), Samsun ilinde 11-14 arası yaş grubuyla yaptığı çalışmada obezite prevalansı $\% 10,3$, aşırı kilolu olma prevalansı kızlarda \%16,6 erkeklerde $\% 27,9$ olarak tespit edilmiştir. Türkiye Beslenme ve Sağlık Araştırması-2010 sonuçlarına göre ise ülkemizde 6-18 yaş arasındaki obez olanlar $\% 8,2$ (erkek \%9,1, kız \%7,3), fazla kilolu olanlar \%14,3 olarak saptanmıştır [3]. Bu yazın araştırma sonuçlarına göre klinik örneklemde 
bulduğumuz obezite oranı ülkemizde toplum örneklemi ile yapılan çalışma sonuçlarına benzerdir. Aşırı kilolu saptadığımız çocuk ve ergenlerin oranı da kısmen düşük olsa da Türkiye Beslenme ve Sağlık Araştırması-2010 sonuçlarına yakındır. Çalışmamızda kız ergenlerde obezite oranlarının erkeklere göre toplum örneklemlerinin tersi şekilde yüksek olması dikkat çekicidir. Bunun sebebi kızların erkeklere göre obezite ile ilişkili depresyon gibi bozukluklara daha fazla sahip olması ve kilolu olma stigmasının kızlarda erkeklere göre daha olumsuz ruhsal sonuçlara yol açması nedeniyle çocuk ve ergen psikiyatrisi kliniklerine obezitesi olan kızların daha sık başvurması olabilir [41, 42].

Çocuk ve ergen psikiyatri popülasyonlarında sağlıklı kontrollere kıyasla daha yüksek obezite ve aşırı kilolu olma oranları olduğunu gösteren çalışmalar bulunmaktadır $[4,5]$. Bunun yanı sıra, özel tanı gruplarında yapılan çalışmalarda farklı yönde bulgular da sunulmuştur. Örneğin, klinik örneklemde ergenlerde ilaç kullanmayan ilk atak geçiren psikotik ve bipolar bozukluklarda obezite oranları normal akranlarından farklı bulunmamıştır $[43,44]$. Bununla birlikte, Dikkat Eksikliği ve Hiperaktivite Bozukluğu (DEHB) ve Otizm Spektrum Bozuklukları (OSB) ile yapılan klinik ve toplum örneklemli çalışmalar, DEHB'li bireylerde \%14,7 obezite ve \%20,9 aşırı kilolu olma, OSB'li bireylerde \%21,8 obezite ve $\% 19,8$ aşırı kilolu olma oranları raporlamıştır [45]. Dolayısıyla çocuk ve ergen ruh sağlığı yönüyle genel yazın bilgisi, klinik örneklemde obezite ve aşırı kiloya sahip olmanın topluma göre daha sık olduğunu destekler niteliktedir. Çalışmamızdaki obezite oranının toplum örneklem değerlerine yakın olması ve diğer çalışmaların klinik örneklemde raporladığı oranlara kıyasla görece düşük olması, çalışmalar arası klinik örneklemi oluşturan hasta popülasyonu farklılıklarına, ayrıca katılımcıların farklı yaş aralıklarında olmasına ve çalışmaların yapıldığı farklı ülkelerdeki obeziteyi etkileyen diğer faktörlere bağlanabilir.

Çalışmamızda anne eğitimi lise ve üstü olan çocuk ve ergenlerin anne eğitimi ortaokul ve altı olanlara göre BKİ oranları anlamlı derecede fazla bulunurken, anne çalışma durumu, baba eğitim durumu ve aile gelir düzeyine göre BKI arasında anlamlı farklılık saptanmamıştır. Anne eğitim düzeyinin artması ile BKI arasındaki pozitif ilişki, ebeveyn yükseköğretim düzeyinin gelişmiş ülkelerin tersine gelişmekte olan ülkelerde çocukların fazla kilolu olmasıyla ilişkili bulunmasıyla uyumludur [46]. Metinoğlu ve ark.'nın [47] yaptığı çalışmada baba eğitim durumu, aile gelir düzeyine göre BKİ arasında çalışmamıza benzer şekilde fark bulunmamıştır. Yine başka bir çalışmada aşırı kilolu/obez 1116 yaş arası çocuk ve ergenlerin normal kilolu olan yaşıtlarına göre anne çalışma durumu, anne eğitim durumu, baba eğitim durumu açısından farklılık göstermediği tespit edilmiştir [48]. Sosyodemografik değişkenlerle BKI arasındaki ilişki, daha geniş örneklemlerde, alt grupları kapsayacak şekilde ele alınan toplum çalışmalarıyla daha iyi şekilde ortaya konulabilir.

Çalışmamızda BTÖ puan ortalaması $8,29 \pm 2,85$ olarak bulunmuştur. Kızlar ve erkekler arasında beslenme tutumları açısından fark saptanmamıştır. BTÖ'nün 315 öğrenci ile yapılan Türkçe geçerlilik güvenirlilik çalışmasında ortalama puan $13,6 \pm 2,0$ olarak raporlanmıştır [36]. Başka bir çalışmada ise 8-11 yaş aralığındaki çocuklarda BTÖ ortalaması 13,97 $\pm 2,14$ tespit edilmiştir [49]. Çalışmamız sonuçları toplum örneklemli bu çalışma sonuçlarıyla karşılaştırıldığında, çocuk ve ergen psikiyatri polikliniklerine başvuran olguların beslenme tutumlarının daha sağlıksız olduğunu düşündürmektedir. Ancak bu durum yorumlanırken, yukarıda bahsedilen toplum örneklemli çalışmaların bizim örneklemimizden daha küçük yaş gruplarında yapıldığı dikkate alınmalıdır. Çagan ve ark.'nın [49] yaptığı çalışmada kızların erkeklere göre anlamlı derecede daha olumlu beslenme tutumlarına sahip olduğu bulunmuştur. Genel olarak kızlar meyve ve sebze gibi düşük kalorili yiyecekleri tüketmeyi tercih ederken, erkekler daha sağlıksız ürünleri tüketmeyi tercih eder [50, 51]. Bununla birlikte yeme bozuklukları ve riskli yeme davranışları kızlarda erkeklere göre daha fazladır [52, 53]. Klinik örneklemde yapılan çalışmamızda bu nedenlerle kız ve erkekler arasında beslenme tutumları açısından fark bulunmamış olabilir.

Çalışmamızda çocuk ve ergenlerin beslenme davranışını değerlendirdiğimiz BDÖ puan ortalaması negatif değer alarak $(-1,69 \pm 4,79)$ sağılılı beslenme alışkanlığının örneklemimizde oldukça düşük olduğunu göstermiştir. Ülkemizde 12-14 yaş ergenlerle toplum örnekleminde yapılan bir çalışma, BDÖ 
puan ortalamasını 1,28 $\pm 5,45$ olarak bulmuş, çalışmanın yazarları bu ortalamayı oldukça düşükbularakbuyaş grubunun sağlıksız besinleri tüketme eğiliminde olduğunu ileri sürmüşlerdir [54]. Ülkemizde ortaokul örneklemi ile yapılan çalışmaların birinde BDÖ puan ortalaması $9,1 \pm 4,4$ olarak diğerinde kızlarda 1,64 $\pm 5,17$ erkeklerde 1,18 $\pm 5,22$ olarak bulunmuştur [39, 55]. Bizim çalışmamızda kız ve erkekler arasında BDÖ puanları arasında anlamlı bir farklılık bulunmamıştır. Bu açıdan çalışmamız Akil ve Top [55] tarafından Uşak'ta ortaokul öğrencileri ile yapılan çalışma sonuçlarıyla benzerdir. Diğer çalışmaların birinde cinsiyet açısından puanlar karşılaştırılmamış diğerinde ise erkeklerde kızlara göre kısmen yüksek bulunmuştur [39, 54]. Bu çalışmaların sonuçlarına kıyasla bizim çalışma sonuçlarımız değerlendirildiğinde çocuk ve ergen psikiyatrisi polikliniklerine başvuran 11-16 yaş arası çocuk ve ergenlerin topluma göre daha sağlıksız beslenme davranışlarına sahip olma eğiliminde olduğu görülmektedir. Ancak bu bulgunun desteklenmesi için farklı çocuk ve ergen psikiyatrisi kliniklerinde benzer çalışmaların yapılmasına ihtiyaç vardır.

Çalışmamızda BTÖ, BDÖ ile anne eğitimi, anne çalışma durumu, baba eğitimi ve aile gelir düzeyleri arasında bir farklılık bulunmamıştır. Çetinkaya ve ark.'nın [56] yaptığı bir çalışmada da sağlıklı beslenme açısından anne eğitimi, baba eğitimi ve aile gelir düzeyi arasında bir ilişki bulunmamıştır. Lise öğrencileri ile yapılan bir başka çalışmada da anne-baba çalışma, anne-baba eğitim durumu ve aile gelir düzeyine göre olumlu ya da olumsuz beslenme özellikleri arasında fark bulunmamıştır [57]. Klinik örneklemden çalışma sonuçlarımız, ülkemizde toplum örnekleminde benzer soruları araştıran çalışma sonuçları ile uyumlu gözükmektedir. Ancak beslenme alışkanlıklarının çoklu sosyokültürel değişkenlerden etkilenmeye açık olduğu da akılda tutulmalıdır [58].

Çalışmamızda "her sabah iyi bir kahvaltı yapmayı seviyorum" cümlesine katılmayan çocuk ve ergenlerin oranı $\% 74,5$ olarak bulunmuştur. $\mathrm{Bu}$ oran sabah kahvaltısı öğününün sıklıkla atlandığını gösteren önceki çalışmalarla uyumludur $[47,59,60]$. Kahvaltı öğününü atlamak çocuk ve ergenlerde aşırı kilolu olma, obez olma, kötü lipit profili, insülin direnci ve metabolik sendromla ilişkilidir [60]. Kahvaltı yapmanın ve kahvaltıda sağlıklı beslenmenin çocuk ve ergenlerin bilişsel ve okul performanslarına olumlu etkileri olduğu bilinmektedir [61, 62]. Bu nedenlerle çocuk ve ergen psikiyatri polikliniklerine başvuranlarda sağlıklı beslenme tutumları açısından sabah kahvaltısının önemle ele alınmasının gerekli olduğu düşünülmüştür. Çalışmamıza katılan çocuk ve ergenlerin \%66,9'u "sebze yemeyi seviyorum" cümlesine olumsuz yanıt vermiştir. Kutlu ve Çivi'nin [17] 7-14 yaş aralığında yürüttükleri araştırmasında katılımcıların \%53,6'sının sebze grubu besinleri yetersiz tükettiği bulunmuştur. Yapılan başka bir çalışmada ise ortaokul ve lise öğrencilerinin sadece \%32'sinin her gün önerilen şekilde beş porsiyon sebze ve meyve tükettiği bildirilmiştir [63]. Dolayısıyla, toplum örneklemine benzer şekilde çocuk ve ergen psikiyatri polikliniklerine başvuran olgularda da sebze tüketiminin az olduğu anlaşılmaktadır. Çalışmamızda "Her gün sağlıklı besinler yemeyi seviyorum" ve "Okuldan sonra acıktığımda meyve ya da benim için faydalı olduğuna inandığım bir şey yiyorum" cümlelerine olumsuz yanıt veren katılımcıların oranı sırayla \%67,4 ve \%71'dir. Yapılan yurt içi ve yurt dışı çalışmalarda çocuk ve ergenlerin öğün aralarında şeker, çikolata, gazlı içecekler, hamburger gibi sağlıksız besinler tükettikleri saptanmıştır [19, 64-66]. Çalışmamız çocuk ve ergen polikliniklerine başvuran 11-16 yaş arası olguların sağlıksız besin tercih etme tutumlarının olduğunu göstermektedir. Bununla birlikte klinik örneklemdeki çocuk ve ergenlerin toplum örnekleminden beslenme tutumları açısından daha farklı olup olmadığının anlaşılması için toplum ve klinik örneklemini karşılaştıran çalışmalara intiyaç vardır.

Çalışmamızda BKİ ile GGAile değerlendirilen psikometrik özellikler arasında herhangi bir ilişki bulunmamıştır. Klinik örneklemde obezlerde yapılan çalışmalarda dışa yönelim ve içe yönelimle ilgili bozuklukların; DEHB, depresyon bozukluğu olanlarda da aşırı kilolu olma ve obezitenin arttığını gösteren çalışmalar vardır [6-8, 67, 68]. Toplum örneklemli bir çalışmada ailenin doldurduğu GGA'ya göre akran sorunları ile BKI arasında pozitif bir ilişki bulunmuş; kızlarda emosyonel sorunlar, erkeklerde davranım sorunları ile BKI arasında ilişki tespit edilmiştir [14]. Ancak BKİ ya da aşırı kilolu/obez olma ile ruhsal sorunlar arasında hiçbir ilişki bulmayan $[9,10]$ ya da akran sorunları dışında hiçbir ilişki belirlemeyen toplum örneklemli 
çalışmalar da vardır [69]. Çalışma sonuçlarımız yorumlanırken örneklemimizin genel klinik örneklem olduğu dikkate alınmalı, çalışmalar arası yaş grubu farklılıkları ve beslenme ile ilgili kültürel farklılıklar olabileceği göz önünde bulundurulmalıdır. Akılda tutulması gereken diğer bir nokta da çalışmamızda ergenlerin beden kilo algısının değerlendirilmemiş olmasıdır. Ergenlerin beden algıları ile ilgili olumsuz düşüncelerinin BKI'ye göre içe yönelim ve dışa yönelim sorunları ile daha ilişkili olduğu bulunmuştur [70]. Çalışmamızda BKI ile BTÖ arasındaki zayıf da olsa negatif ilişki varlığı, obezlerde beklenildiği gibi sabah kahvaltısını atlama, sebze tüketiminin az olması gibi beslenme tutumlarının bozuk olduğunu gösteren önceki çalışmalarla uyumludur [71]. Ancak çalışmamızda BKI ile BDÖ arasında anlamlı bir ilişki saptanamamıştır. BKI ile yeme alışkanlıkları arasındaki ilişkiyi araştıran bazı çalışmalar da tutarsız sonuçlar bildirmiştir, artan BKİ ile abur cubur veya şekerli içecek tüketimi arasında hiçbir ilişki göstermeyen çalışmalar yanında fazla kilolu çocuklar arasında abur cubur alımında artış olduğunu bildiren çalışmalar vardır [72]. Çalışmamızda BKI ile bir ilişkisi bulunmamasına rağmen oldukça yüksek oranda olumsuz beslenme davranışları saptanmıştır. Buradan yola çıkarak çocuk ve ergen psikiyatri kliniklerinde sağlıklı beslenmeye yönelik plan ve psikoeğitimlerin yalnızca şu anda aşırı kilolu veya obez olanları değil, tüm çocuk ve ergenleri hedeflemesi önerilebilir.

Çalışmamız, davranış sorunları, hiperaktivitedikkat eksikliği ve GGA'dan alınan toplam puan arttıkça olumsuz beslenme tutumlarının fazlalaştığını saptamıştır. Yapılan çalışmalar sebze, meyve ve balık gibi "sağlıklı besinlerle beslenen" ergenlerin daha iyi ruh sağlığına sahip olduğu göstermiştir [29]. Bu açıdan çalışmamız sonucunda bulduğumuz toplam güçlük puanı ile beslenme tutumu arasındaki negatif ilişki yazın bilgisi ile uyumludur. Ayrıca çalışmalar sağlıklı beslenen ergenlerde daha düşük dikkat eksikliği hiperaktivite bozukluğu tanısı, belirtileri ve davranışsal sorunlar yaşandığını göstermektedir [25, 29, 72-75]. Yine DEHB belirtileri olan çocuk ve ergenlerin kontrol grubuna göre daha çok oranda sabah kahvaltısı atlama eğiliminde oldukları gösterilmiştir [76, 77]. Çalışma sonucumuz polikliniğe başvuran dışa yönelim sorunları (davranım sorunları ve hiperaktivite- dikkat eksikliği) yaşayan çocuk ve ergenlerin olumsuz beslenme tutumlarına sahip olduğunu göstermiştir. Yakın zamanda yapılan bir meta-analiz çalışması, DEHB tanısı olan ergenlerin aşırı kilolu olma olasılığının 1,1 kat arttığını, yetişkinlerde bu oranın 1,37 olduğunu ortaya koymuştur [78]. Bu bilgiler DEHB'si olan ergenlerin beslenme tutumlarındaki bozuklukların, yetişkin dönemde DEHB'lilerde görülen obezitenin sebeplerinden biri olabileceğini düşündürebilir. Ancak bu ilişkinin boylamsal çalışmalarla gösterilmesine ihtiyaç vardır. Yukarıda ele alınan beslenme tutumları ile bilişsel performans arasındaki ilişki, DEHB olan ve olmayan üniversite öğrencilerinde kahvaltı yapmanın bilişsel işlevleri düzelttiği yönündeki yazın bilgisi ile birleştirildiğinde [79], çocuk ve ergen psikiyatri kliniklerinde izlenen DEHB tanısı olan çocuk ve ergenlerde beslenme tutumlarını iyileştirmeye yönelik yaklaşımların tedavinin bir parçası olarak ele alınmasında yarar olacağını düşündürmüştür.

Çalışmamızda BTÖ ve GGA duygusal, akran sorunları ile sosyal davranış alt ölçekleri arasında bir ilişki bulunmamıştır. Yazın araştırmalarına göre sağlıksız beslenme ile ergenlerdeki depresyon ve anksiyete belirtileri arasında pozitif yönde bir ilişki mevcuttur [80-82]. Ancak bu ilişkinin küçük etki büyüklüğüne sahip olduğu ve ergenlerde çalışma sonuçlarının tutarsız olduğu da belirtilmiştir [80, 83]. Çalışmamızda bu ilişkinin saptanamamış olmasının nedeni örneklem farklılığı, yaş aralıklarının farklı olması, bu küçük etki büyüklüğüne sahip ilişkiyi saptamak için yeterli örnekleme sahip olmamamız olabilir.

Çalışmamızda BDÖ puanları ile GGA sosyal davranışlar alt ölçeği arasında pozitif yönlü zayıf bir ilişki saptanmış, diğer alt ölçekler ve toplam puanla bir ilişki bulunmamıştır. Prososyal davranışlar ile belirli beslenme kalıpları arasındaki ilişki hakkında hala çok az bilgi mevcuttur, bu nedenle bulgumuzun yorumlanması kolay değildir. Ancak prososyal davranışlarla olumlu beslenme arasındaki pozitif yönde ilişki varlığına dair önceki çalışmalardan gelen kanıtlar mevcuttur [84, 85]. Bu alanda daha fazla araştırmaya ihtiyaç vardır. Toplum örneklemli bir çalışmada şekerli içecekler ve atıştırmalıkların tüketimi ergenlerdeki psikiyatrik rahatsızlıkla, tuzlu yiyeceklerin tüketimi ise şiddet davranışlarıyla ilişkili bulunmuştur [82]. 
Ancak İranlı kız ergenlerle yapılan bir çalışmada GGA ile besim alımları arasında bir ilişki tespit edilmemiştir [86]. Bununla birlikte başka bir çalışmada sadece kızlarda sağlıksız besin tüketimi dışa yönelim sorunları ile ilişkili bulunmuş ancak erkeklerde herhangi bir ilişki gösterilmemiştir [30]. Bu çalışma sonuçları kısmen çalışma sonuçlarımızı desteklemektedir, ancak bizim çalışmamızın toplum örneklemli bu çalışmalardan farklı olarak klinik örneklemde ve farklı bir kültürde yapılmış olması, yaş olarak sadece 11-16 yaş arasını değerlendirmesi BDÖ ile belirlenen sağlıksız besin tüketimi ile içe ve dışa yönelim sorunları arasında bir ilişki bulamamamızın nedenleri olabilir.

Çocuk ve ergen psikiyatri polikliniklerine başvuran 11-16 yaş arası çocuk ve ergenlerin BKI, beslenme tutum, davranışları ve bunların duygusal ve davranışsal sorunlar ile ilişkisini ulaşılabildiği kadarıyla ülkemizde ilk defa inceleyen çalışmamızın sonuçlarını yorumlarken aşağıdaki kısıtılıklar dikkate alınmalıdır. Birincisi çalışmamızda elde edilen veriler öz bildirim ölçeklerinden oluşmaktadır. İkincisi beslenme alışkanlıkları üzerinde etkili olan günlük fiziksel aktivite miktarı ve ekran süresi gibi değişkenler çalışmamızda değerlendirilmemiştir. Üçüncüsü beslenme ile ilgili ruhsal sorunlarla bulduğumuz ilişki iki yönlü olabilir. Ancak çalışmamız kesitsel bir çalışma olduğundan bu iki yönlü ilişki olasılığı ele alınamamıştır. Dördüncüsü ergenlerin beslenme alışkanlıklarında ailesel kuralların da etkisi vardır, çalışmamız bu ailesel etkiyi incelememiştir [66]. Beşincisi psikotrop ilaçların iştah ve kilo üzerine etkileri olduğu bilinmektedir [87, 88]. Çalışmamızda bu etkiler dışlanmamıştır. Son olarak sosyoekonomik düzey ile beslenme alışkanlıkları arasında ilişki bulan çalışma sonuçları ile çalışmamız bulgularını karşılaştırmaya imkan verecek farklı sosyoekonomik düzey grupları çalışmamızda sağlanamadığından bu konuda sağlıklı bir değerlendirme yapılamamıştır [89].

Sonuç olarak çocuk ve ergen psikiyatrisi polikliniklerine başvuran 11-16 yaş arası çocuk ve ergenlerde obezite ve aşırı kilolu olma oranları toplum örneklemine benzer bulunmuştur. Ancak bu grup daha olumsuz beslenme tutum ve davranışlarına sahip görünmektedir. Davranış sorunları ve hiperaktivite belirtilerinin artması olumsuz beslenme tutumları ile ilişkiliyken, çocuk ve ergenlerin iyi sosyal davranış becerileri beslenme davranışını olumlu yönde etkilemektedir. Beslenme tutum ve davranışları ile psikiyatrik faktörlerin ilişkisinin belirlenmesi hem beslenme hem de ruhsal bozuklukların anlaşılması ve önlenmesi konusunda yol gösterici olabilir. Çocuk ve ergenlerde olumlu beslenme tutum ve davranışlarının geliştirilmesi tedavi girişimlerinin bir parçası olarak ele alınmalıdır.

Çıkar ilişkisi: Yazarlar çıkar ilişkisi olmadığını beyan eder.

\section{Kaynaklar}

1. WHO | Why does childhood overweight and obesity matter? Available at: https://www.who.int/news-room/ q-a-detail/noncommunicable-diseases-childhoodoverweight-and-obesity. Accessed December 14, 2020

2. $\mathrm{Ng} \mathrm{M}$, Fleming $\mathrm{T}$, Robinson $\mathrm{M}$, et al. Global, regional, and national prevalence of overweight and obesity in children and adults during 1980-2013: a systematic analysis for the Global Burden of Disease Study 2013. Lancet 2014;384:766-781. https://doi.org/10.1016/ S0140-6736(14)60460-8

3. Türkiye'de Obezitenin Görülme Sıklığı. Available at: $\quad$ https://hsgm.saglik.gov.tr/tr/obezite/turkiyedeobezitenin-gorulme-sikligi.html. Erişim tarihi 15 Aralık 2020

4. Gracious BL, Cook SR, Meyer AE, et al. Prevalence of overweight and obesity in adolescents with severe mental illness: a cross-sectional chart review. J Clin Psychiatry 2010;71:949-954. https://doi.org/10.4088/ JCP.09m05033gre

5. Vieweg WVR, Kuhnley LJ, Kuhnley EJ, et al. Body mass index (BMI) in newly admitted child and adolescent psychiatric inpatients. Prog NeuroPsychopharmacology Biol Psychiatry 2005;29:511515. https://doi.org/10.1016/j.pnpbp.2005.01.001

6. Erickson SJ, Robinson TN, Farish Haydel K, Killen JD. Are overweight children unhappy? Body mass index, depressive symptoms, and overweight concerns in elementary school children. Arch Pediatr Adolesc Med 2000;154:931-935. https://doi.org/10.1001/ archpedi.154.9.931

7. Britz B, Siegfried W, Ziegler A, et al. Rates of psychiatric disorders in a clinical study group of adolescents with extreme obesity and in obese adolescents ascertained via a population based study. Int J Obes 2000;24:17071714. https://doi.org/10.1038/sj.ijo.0801449

8. Sagar R, Gupta T. Psychological aspects of obesity in children and adolescents. Indian J Pediatr 2018;85:554559. https://doi.org/10.1007/s12098-017-2539-2 
9. Lamertz CM, Jacobi C, Yassouridis A, Arnold K, Henkel AW. Are obese adolescents and young adults at higher risk for mental disorders? A community survey. Obes Res 2002;10:1152-1160. https://doi.org/10.1038/ oby.2002.156

10. Wardle J, Williamson S, Johnson F, Edwards C. Depression in adolescent obesity: cultural moderators of the association between obesity and depressive symptoms. Int J Obes 2006;30:634-643. https://doi. org/10.1038/sj.ijo.0803142

11. Wardle J, Cooke L. The impact obesity on psychological well-being. Best Pract Res Clin Endocrinol Metab 2005;19:421-440. https://doi.org/10.1016/j. beem.2005.04.006

12. Sutaria S, Devakumar D, Yasuda SS, Das S, Saxena S. Is obesity associated with depression in children? Systematic review and meta-analysis. Arch Dis Child 2019;104:64-74. https://doi.org/10.1136/ archdischild-2017-314608

13. Xie B, Ishibashi K, Lin C, Peterson D V., Susman EJ. Overweight trajectories and psychosocial adjustment among adolescents. Prev Med 2013;57:837-843. https://doi.org/10.1016/j.ypmed.2013.09.008

14. Bjertnaes AA, Fossum IN, Oma I, Bakken KS, Arne T, Holten Andersen MN. A cross-sectional study of the relationship between mental health problems and overweight and obesity in adolescents. Front Public Heal 2020;8:334. https://doi.org/10.3389/ fpubh.2020.00334

15. Otçeken Kurtaraner M. Obezitesi olan ve olmayan 14 - 17 yaş aralığındaki ergenlerin ruhsal süreçlerinin, beden algıları,aile özellikleri ve beslenme alışkanlıkları yönünden incelenmesi. Yayımlanmamış yüksek lisans tezi. İstanbul Bilim Üniversitesi, Sosyal Bilimler Enstitüsü, İstanbul, 2012.

16. Kivimäki M, Lawlor DA, Singh Manoux A, et al. Common mental disorder and obesity-Insight from four repeat measures over 19 years: prospective Whitehall II cohort study. BMJ 2009;339:3765. https:// doi.org/10.1136/bmj.b3765

17. Kutlu R, Çivi S. Özel bir ilköğretim okulu öğrencilerinde beslenme alışkanlıklarının ve beden kitle indekslerinin değerlendirilmesi. Fırat Tıp Derg 2009;14:18-24. Erişim adresi: http://www.firattipdergisi.com/pdf/pdf_ FTD_533.pdf. Erişim tarihi 15 Aralık 2020

18. Moreno LA, Rodríguez G, Fleta J, Bueno Lozano M, Lázaro A, Bueno G. Trends of dietary habits in adolescents. Crit Rev Food Sci Nutr 2010;50:106-112. https://doi.org/10.1080/10408390903467480

19. Kann L, McManus T, Harris WA, et al. Youth risk behavior surveillance United States, 2015. MMWR Surveill Summ 2016;65:1-174. https://doi.org/10.15585/mmwr. ss6506a1
20. Koca T, Akcam M, Serdaroglu F, Dereci S. Breakfast habits, dairy product consumption, physical activity, and their associations with body mass index in children aged 6-18. Eur J Pediatr 2017;176:1251-1257. https:// doi.org/10.1007/s00431-017-2976-y

21. Savige GS, Ball K, Worsley A, Crawford D. Food intake patterns among Australian adolescents. Asia Pac J Clin Nutr 2007;16:738-747. https://doi.org/10.6133/ apjcn.2007.16.4.22

22. Emmett PM, Jones LR. Diet, growth, and obesity development throughout childhood in the Avon Longitudinal Study of Parents and Children. Nutr Rev 2015;73:175-206. https://doi.org/10.1093/nutrit/nuv054

23. León Muñoz LM, García Esquinas E, Soler Vila H, Guallar Castillón P, Banegas JR, Rodríguez Artalejo F. Unhealthy eating behaviors and weight gain: a prospective study in young and middle-age adults. Obesity 2016;24:1178-1184. https://doi.org/10.1002/ oby. 21477

24. Jacka FN, Rothon C, Taylor S, Berk M, Stansfeld SA. Diet quality and mental health problems in adolescents from East London: a prospective study. Soc Psychiatry Psychiatr Epidemiol 2013;48:1297-1306. https://doi. org/10.1007/s00127-012-0623-5

25. Jacka FN, Kremer PJ, Berk M, et al. A prospective study of diet quality and mental health in adolescents. PLoS One 2011;6:24805. https://doi.org/10.1371/ journal.pone. 0024805

26. Jacka FN, Kremer PJ, Leslie ER, et al. Associations between dietquality and depressed mood inadolescents: results from the Australian Healthy Neighbourhoods Study. Aust NZJ Psychiatry 2010;44:435-442. https:// doi.org/10.3109/00048670903571598

27. Kohlboeck G, Sausenthaler S, Standl M, et al. Food intake, diet quality and behavioral problems in children: results from the GINI-plus/LISA-plus studies. Ann Nutr Metab 2012;60:247-256. https://doi. org/10.1159/000337552

28. Moon SJ, Kim JW, Kim HJ, Lee DK. Association between dietary habits and mental health in korean adolescents: a study based on the 10th (2014) Adolescent Health Behavior Online Survey. Korean J Fam Pract 2017;7:66-71. https://doi.org/10.21215/ kjfp.2017.7.1.66

29. Del Ponte B, Quinte GC, Cruz S, Grellert M, Santos IS. Dietary patterns and attention deficit/hyperactivity disorder (ADHD): a systematic review and metaanalysis. J Affect Disord 2019;252:160-173. https://doi. org/10.1016/j.jad.2019.04.061

30. Trapp GSA, Allen KL, Black LJ, et al. A prospective investigation of dietary patterns and internalizing and externalizing mental health problems in adolescents. Food Sci Nutr 2016;4:888-896. https://doi.org/10.1002/ fsn3.355 
31. O'Neil A, Quirk SE, Housden S, et al. Relationship between diet and mental health in children and adolescents: a systematic review. Am J Public Health 2014;104:31-42. https://doi.org/10.2105/ AJPH.2014.302110

32. Neyzi $O$, Günöz H, Furman A, ve ark. Türk çocuklarında vücut ağırığı, boy uzunluğu, baş çevresi ve vücut kitle indeksi referans değerleri. Çocuk Sağlığı ve Hastalıkları Dergisi 2008;51:1-14. Erişim adresi: http:// www.cshd.org.tr/uploads/pdf_CSH_279.pdf. Erişim tarihi 01 Haziran 208

33. Goodman R. The strengths and difficulties questionnaire:a research note. J Child Psychol Psychiatry 1997;38:581586. https://doi.org/10.1111/j.1469-7610.1997. tb01545.x

34. Güvenir T, Özbek A, Baykara B, Arkar H, Şentürk B, İncekaş $S$. Güçler ve güçlükler anketīnin (GGA) Türkçe uyarlamasının psikometrik özelliklerì. Çocuk ve Gençlik Ruh Sağlığı Derg 2008;15:65-74. Erişim adresi: http://cms.galenos.com.tr/Uploads/Article_30252/ cogepderg-15-65.pdf. Erişim tarihi 17 Aralık 2020

35. Arvidson C. Children's cardiovascular health promotion attitude scale: an instrument development. Denton, TX, USA.: Texas Woman's University; 1990.

36. Haney MÖ, Bahar Z. Çocuk kalp sağlığını geliştirme tutum ölçeği'nin geçerlik ve güvenirliği. Dokuz Eylül Üniversitesi Hemşirelik Fakültesi Elektron Derg 2014;7:92-97. Erişim adresi: https://dergipark.org.tr/ tr/pub/deuhfed/issue/46808/586994. Erişim tarihi 17 Aralık 2020

37.Edmundson E, Parcel GS, Feldman HA, et al. The effects of the child and adolescent trial for cardiovascular health upon psychosocial determinants of diet and physical activity behavior. Prev Med 1996;25:442-454. https://doi.org/10.1006/pmed.1996.0076

38. Öztürk $M$, Erdoğan S. Çocukların beslenme alışkanlıklarının sağlık davranışı etkileşim modeline göre incelenmesi. Yayınlanmamış doktora tezi. İstanbul Üniversitesi Sağlık Bilimleri Enstitüsü, İstanbul, 2010.

39. Yılmaz A, Kocotaş S. Obesity prevalence, nutritional behaviors and physical activity levels in the secondary school students. J Public Heal Nurs 2019;1:6683. Available at: https://dergipark.org.tr/tr/pub/jphn/ issue/48387/590808. Accessed December 17, 2020

40. Dündar $\mathrm{C}$, Öz H. Obesity related factors in Turkish school children. Sci World J 2012;2012:5. https://doi. org/10.1100/2012/353485

41. Mannan M, Mamun A, Doi S, Clavarino A. Prospective associations between depression and obesity for adolescent males and females: a systematic review and meta-analysis of longitudinal studies. PLoS One 2016;11:e0157240. https://doi.org/10.1371/journal. pone. 0157240
42. Tronieri JS, Wurst CMC, Pearl RL, Allison KC. Sex differences in obesity and mental health Curr Psychiatry Rep 2017;19:29. https://doi.org/10.1007/s11920-0170784-8

43. Jensen KG, Correll CU, Rudå D, et al. Pretreatment cardiometabolic status in youth with early-onset psychosis: baseline results from the TEA trial. J Clin Psychiatry 2017;78:e1035-1046. https://doi. org/10.4088/JCP.15m10479

44. Goldstein BI, Blanco C, He JP, Merikangas K. Correlates of overweight and obesity among adolescents with bipolar disorder in the National Comorbidity SurveyAdolescent Supplement (NCS-A). J Am Acad Child Adolesc Psychiatry 2016;55:1020-1026. https://doi. org/10.1016/j.jaac.2016.08.010

45. Li Y, Xie X, Lei X, Li Y, Lei X. Global prevalence of obesity, overweight and underweight in children, adolescents and adults with autism spectrum disorder, attentiondeficit hyperactivity disorder: a systematic review and meta-analysis. Obes Rev 2020;21:e13123. https://doi. org/10.1111/obr.13123

46. Muthuri SK, Francis CE, Wachira LJ, et al. Evidence of an overweight/obesity transition among schoolaged children and youth in Sub-Saharan Africa: a systematic review. PLoS One 2014;9:e92846. https:// doi.org/10.1371/journal.pone.0092846

47. Metinoğlu I, Pekol S, Metinoğlu Y. Kastamonu'da 10-12 yaş grubu öğrencilerde obezite prevalansı ve etkileyen faktörler. Acıbadem Üniversitesi Sağlık Bilim Derg 2012;3:117-123. https://doi.org/10.17942/sted.551556

48. Uğuz AM, Bodur S. Konya il merkezindeki ergenlik öncesi ve ergen çocuklarda aşırı ağırlık ve şişmanlık durumunun demografik özelliklerle ilişkisi. Genel Tıp Derg 2007;17:1-7. Erişim adresi: http://geneltip.org/ upload/sayi/51/GTD-00384.pdf. Erişim tarihi 17 Aralık 2020

49. Cagan O, Unsal A. Study of the relationship between nutritional attitude of primary school students and child feeding attitude of the parents. Res Commun Pyschology Psychiatry Behav 2017;3:1-5. http:// rcppb.europeansp.org/article-6-226-en.html. Accepted December 14, 2020

50. Reynolds KD, Baranowski T, Bishop DB, et al. Patterns in child and adolescent consumption of fruit and vegetables: effects of gender and ethnicity across four sites. J Am Coll Nutr 1999;18:248-254. https://doi.org/1 0.1080/07315724.1999.10718859

51. Wah CS. Gender differences in eating behaviour. Int J Bus Econ Man 2016;4:116-121. https://doi. org/10.24924/ijabm/2016.11/v4.iss2/116.121

52. Galmiche M, Déchelotte P, Lambert G, Tavolacci MP. Prevalence of eating disorders over the 2000-2018 period: a systematic literature review. Am J Clin Nutr 2019;109:1402-1413. https://doi.org/10.1093/ajcn/ nqy342 
53. Ivanova MR, Bakova D, Semerdjieva M, Torniova B, Tilov B, Raikova E. Disordered eating attitudes and behaviors: gender differences in adolescence and young adulthood. J Womens Heal Care 2017;06:368. https://doi.org/10.4172/2167-0420.1000368

54. Keskin K, Alpkaya U, Çubuk A, Öztürk Y. 2-14 yaş çocukların fiziksel aktivite düzeyleri ile beslenme davranışları arasındaki ilişkinin incelenmesi. Ï̈ Spor Bilimleri Dergisi 2017;7:34-43.

55. Akil M, Top E. Obesity awareness and nutrition behavior of children students in Uşak province, Republic of Turkey. J Gizi dan Pangan 2019;14:1-8. https://doi. org/10.25182/jgp.2019.14.1.1-8

56. Cetinkaya AC, Tayhan A, Özmen D, Uyar F. Beden kitle indeksleri ve beden algılarına göre adölesanların yaşam biçimlerinin incelenmesi. Anadolu Hemşirelik ve Sağlık Bilim Derg 2017;20:160-169. Erişim adresi: https://www.researchgate.net/profile/Damla_Sahin_ Bueyuek/publication/327308103.pdf. Erişim tarihi 17 Aralık 2020

57. Yıldırım S, Uskun E, Kurnaz M. Bir il merkezinde liselerde eğitim gören öğrencilerin yeme tutumları ve ilişkili faktörler. J Pediatr Res 2017;4:149-155. https:// doi.org/10.4274/jpr.97659

58. Popkin BM, Gordon Larsen P. The nutrition transition: worldwide obesity dynamics and their determinants. Int J Obes Relat Metab Disord 2004;28:2-9. https://doi. org/10.1038/sj.jo.0802804

59. Tanrıverdi D, Savaş E, Gönüllüoğlu N, et al. Lise öğrencilerinin yeme tutumları, yeme davranışları ve benlik saygılarının incelenmesi. Gaziantep Tıp Derg 2011;17:33-39. https://eurjther.com/content/files/ sayilar/16/buyuk/81.pdf. Erişim tarihi 19 Aralık 2020

60. Monzani A, Ricotti R, Caputo M, et al. A systematic review of the association of skipping breakfast with weight and cardiometabolic risk factors in children and adolescents. What should we better Investigate in the future? Nutrients 2019;11:387-410. https://doi. org/10.3390/nu11020387

61. Adolphus K, Lawton CL, Champ CL, Dye L. The effects of breakfast and breakfast composition on cognition in children and adolescents: a systematic review. Adv Nutr 2016;7:590-612. https://doi.org/10.3945/ an. 115.010256

62. Zipp A, Eissing G. Studies on the influence of breakfast on the mental performance of school children and adolescents. J Public Heal 2019;27:103-110. https:// doi.org/10.1007/s10389-018-0926-4

63. Aygün Ö, Karayağız Muslu G. Vegetable and fruit consumption behaviours of secondary and high school students. Turkish J Fam Med Prim Care 2017;11:245255. https://doi.org/10.21763/tjfmpc.359809
64. Erdoğan EG, Akın B. The relationship of body mass indexs in high school students with socio demographic and nutritional characteristics. J Hum Sci 2017; 14:15711589. Available at: https://j-humansciences.com/ojs/ index.php/IJHS/article/view/4475. Accessed December 19, 2020

65. Savaşhan Ç, Sarı O, Aydoğan Ü, Erdal M. İlkokul çağındaki çocuklarda obezite görülme sıklığı ve risk faktörleri. Türk Aile Hek Derg 2015;19:14-21. https:// doi.org/10.15511/tahd.15.01014

66. Holubcikova J, Kolarcik P, Madarasova Geckova A, Van Dijk JP, Reijneveld SA. Lack of parental rule-setting on eating is associated with a wide range of adolescent unhealthy eating behaviour both for boys and girls. BMC Public Health 2016;16:359-367. https://doi. org/10.1186/s12889-016-3002-4

67. Agranat Meged AN, Deitcher C, Goldzweig G, Leibenson L, Stein M, Galili-Weisstub E. Childhood obesity and attention deficit/hyperactivity disorder: a newly described comorbidity in obese hospitalized children. Int J Eat Disord 2005;37:357-359. https://doi. org/10.1002/eat.20096

68. Luppino FS, De Wit LM, Bouvy PF, et al. Overweight, obesity, and depression: a systematic review and meta-analysis of longitudinal studies. Arch Gen Psychiatry 2010;67:220-229. https://doi.org/10.1001/ archgenpsychiatry.2010.2

69. Ren L, Xu Y, Guo X, et al. Body image as risk factor for emotional and behavioral problems among Chinese adolescents. BMC Public Health 2018;18:1179-1189. https://doi.org/10.1186/s12889-018-6079-0

70. ter Bogt TFM, van Dorsselaer SAFM, Monshouwer K, Verdurmen JEE, Engels RCME, Vollebergh WAM. Body mass index and body weight perception as risk factors for Internalizing and externalizing problem behavior among adolescents. J Adolesc Heal 2006;39:27-34. https://doi.org/10.1016/j.jadohealth.2005.09.007

71. Archero F, Ricotti R, Solito A, et al. Adherence to the mediterranean diet among school children and adolescents living in northern Italy and unhealthy food behaviors associated to overweight. Nutrients 2018;10:1322. https://doi.org/10.3390/nu10091322

72. Yannakoulia M, Brussee SE, Drichoutis AC, et al. Food consumption patterns in mediterranean adolescents: are there differences between overweight and normalweight adolescents? J Nutr Educ Behav 2012;44:233239. https://doi.org/10.1016/j.jneb.2010.02.005

73. Oellingrath IM, Svendsen MV, Hestetun I. Eating patterns and mental health problems in early adolescence. A cross-sectional study of 12-13-year-old Norwegian school children. Public Health Nutr 2013;17:25542562. https://doi.org/10.1017/S1368980013002747 
74. Øverby N, Høigaard R. Diet and behavioral problems at school in Norwegian adolescents. Food Nutr Res 2012;56:e17231. https://doi.org/10.3402/fnr. v56i0.17231

75. HowardAL, Robinson M, Smith GJ, Ambrosini GL, PiekJP, Oddy WH. ADHD is associated with a 'Western' dietary pattern in adolescents. J Atten Disord 2011;15:403411. https://doi.org/10.1177/1087054710365990

76. San Mauro Martín I, Blumenfeld Olivares JA, Garicano Vilar E, et al. Nutritional and environmental factors in attention-deficit hyperactivity disorder (ADHD): a cross-sectional study. Nutr Neurosci 2018;21:641-647. https://doi.org/10.1080/1028415X.2017.1331952

77. Rios Hernandez A, Alda JA, Farran Codina A, Ferreira Garcia E, Izquierdo Pulido M. The mediterranean diet and ADHD in children and adolescents. Pediatrics 2017;139:e20162027. https://doi.org/10.1542/ peds.2016-2027

78. Nigg JT, Johnstone JM, Musser ED, Long HG, Willoughby M, Shannon J. Attention-deficit/hyperactivity disorder (ADHD) and being overweight/obesity: new data and meta-analysis. Clin Psychol Rev 2016;43:67-79. https://doi.org/10.1016/j.cpr.2015.11.005

79. Brandley ET, Holton KF. Breakfast positively Impacts cognitive function in college students with and without ADHD. Am J Heal Promot 2020;34:668-671. https:// doi.org/10.1177/0890117120903235

80. Khalid S, Williams CM, Reynolds SA. Is there an association between diet and depression in children and adolescents? A systematic review. $\mathrm{Br}$ J Nutr 2016;116:2097-2108. https://doi.org/10.1017/ S0007114516004359

81. Kim TH, Choi J young, Lee HH, Park Y. Associations between dietary pattern and depression in Korean adolescent girls. J Pediatr Adolesc Gynecol 2015;28:533-537. https://doi.org/10.1016/j. jpag.2015.04.005

82. Zahedi H, Kelishadi R, Heshmat R, et al. Association between junk food consumption and mental health in a national sample of Iranian children and adolescents: the CASPIAN-IV study. Nutrition 2014;30:1391-1397. https://doi.org/10.1016/j.nut.2014.04.014

83. Hong SA, Peltzer K. Dietary behaviour, psychological well-being and mental distress among adolescents in Korea. Child Adolesc Psychiatry Ment Health 2017;11:56-68. https://doi.org/10.1186/s13034-0170194-z

84. Renzaho AMN, Kumanyika S, Tucker KL. Family functioning, parental psychological distress, child behavioural problems, socio-economic disadvantage and fruit and vegetable consumption among 4-12 year-old Victorians, Australia. Health Promot Int 2011;26:263-275. https://doi.org/10.1093/heapro/ daq054
85. Buja A, Grotto G, Brocadello F, Sperotto M, Baldo V. Primary school children and nutrition: lifestyles and behavioral traits associated with a poor to moderate adherence to the Mediterranean diet. A cross-sectional study. Eur J Pediatr 2020;179:827-834. https://doi. org/10.1007/s00431-020-03577-9

86. Farhangi MA, Dehghan P, Jahangiry L. Mental health problems in relation to eating behavior patterns, nutrient intakes and health related quality of life among Iranian female adolescents. PLoS One 2018;13:e0195669. https://doi.org/10.1371/journal.pone.0195669

87. Bou Khalil R, Fares N, Saliba Y, Tamraz J, Richa S. The effect of methylphenidate on appetite and weight. Encephale 2017;43:577-581. https://doi.org/10.1016/j. encep.2017.01.007

88. Correll CU, Manu P, Olshanskiy V, Napolitano B, Kane JM, Malhotra AK. Cardiometabolic risk of second-generation antipsychotic medications during first-time use in children and adolescents. J Am Med Assoc 2009;302:1765-1773. https://doi.org/10.1001/ jama.2009.1549

89. Williamson VG, Dilip A, Dillard JR, Morgan Daniel J, Lee AM, Cardel MI. The influence of socioeconomic status on snacking and weight among adolescents: a scoping review. Nutrients 2020;12:167. https://doi. org/10.3390/nu12010167

Etik kurul onay: Pamukkale Üniversitesi Tıp Fakültesi Klinik Araştırmalar Etik Kurulu'ndan 06.07.2017 tarih ve 60116787-020/43836 karar sayısı ile yerel etik onayı alınmıştır.

Bu çalışma 28. Çocuk ve Ergen Ruh Sağlığı ve Hastalıkları Kongresi'nde (2018), sözel bildiri olarak sunulmuştur.

\section{Yazarların makaleye olan katkıları}

Ö.B., B.K.B. çalışmanın ana fikrini ve hipotezini kurgulamışlardır. Ö.B., B.K.B., C.E., O.C., B.S. teoriyi geliştirmiş ve yöntem ve gereç bölümünü düzenlemişlerdir. C.E., O.C., B.S. verileri toplamışlardır. Sonuçlar kısmındaki verilerin değerlendirmesini Ö.B., B.K.B., C.E., O.C., B.S. yapmışlardır. Makalenin tartışma bölümü Ö.B. ve B.K.B. tarafından yazılmış, C.E., O.D., B.S. gözden geçirip gerekli düzeltmeleri yapmıştır. Ayrıca tüm yazarlar çalışmanın tamamını tartışmış ve son halini onaylamıştır. 